\author{
ANGELIKA PAWLACZYK \\ Uniwersytet Mikołaja Kopernika w Toruniu, Poland \\ https://orcid.org/0000-0002-4629-8952
}

Copyright and License: Copyright by Instytut Języka Polskiego PAN, Kraków 2021. This article is published under the terms of the Creative Commons Attribution - NoDerivatives 4.0 International (CC BY- ND 4.0) License (https:// creativecommons.org/licenses/by-nd/4.0/legalcode.pl).

\title{
SPOŁECZNE UWARUNKOWANIA KOMPETENCJI JEZZYKOWEJ PRZEDSTAWICIELI MNIEJSZOŚCI POLSKIEJ W STRYJU (OBWÓD LWOWSKI)
}

Słowa kluczowe: kompetencja językowa, sytuacja językowa, mniejszość polska, Stryj.

\section{STRESZCZENIE}

Sytuacja mniejszości polskiej mieszkającej w Stryju nie jest jednoznaczna. W zależności od sytuacji komunikacyjnej członkowie wspólnoty posługują się językiem ukraińskim, rosyjskim lub polskim. Ten ostatni jest używany głównie w kontaktach z polskojęzycznymi krewnymi i znajomymi, podczas mszy oraz uroczystości zorganizowanych przez Towarzystwo Kultury Polskiej Ziemi Lwowskiej (TKPZL). W artykule podjęto próbę omówienia społecznych uwarunkowań kompetencji językowej przedstawicieli polskiej mniejszości. Materiał językowy pozyskano podczas letniej szkoły odbywającej się w 2019 roku w stryjskim oddziale TKPZL, a wyniki analizy zestawiono z rezultatami badań pilotażowych przeprowadzonych w 2018 roku w tej samej placówce.

W badaniach wykorzystano dwie metody - kwestionariuszową i wywiadu. Celem pierwszej było zebranie materiału pisanego, zawierającego przekonania respondentów m.in. na temat ich umiejętności językowych. Druga metoda pozwoliła na rozwinięcie przez informatorów (wyrażających chęć omówienia uzupełnionej wcześniej ankiety) przekonań zawartych na piśmie oraz na faktyczną ocenę i weryfikację ich umiejętności. Analiza zgromadzonego materiału wykazała, że obecnie podstawowym narzędziem komunikacji przedstawicieli mniejszości polskiej w Stryju jest język ukraiński, a polszczyzna jest używana albo okazjonalnie, albo praktycznie w ogóle nie jest przez nich używana. Zarówno w ankietach, jak i w wywiadach respondenci/ informatorzy przejawiali dbałość o zgodność z normą literacką języka polskiego. Na dokładniejszą ocenę umiejętności językowych i weryfikację odchyleń od normy pojawiających się w wypowiedziach pozwalała spontaniczna zmiana tematu rozmowy podczas wywiadów. W toku prowadzonych badań wykazano, że polszczyzna zajmuje wysoką pozycję w systemie wartości przedstawicieli mniejszości polskiej w Stryju, co wynika m.in. z chęci zachowania języka przodków i podtrzymania rodzinnych tradycji. Mimo że obecnie jest używana okazjonalnie, to obserwuje się wzrost zainteresowania nią we wszystkich pokoleniach, a zwłaszcza - w pokoleniu młodszym. Wynika to nie tylko z więzów krwi, lecz także z atrakcyjności samego języka polskiego. 


\section{WPROWADZENIE}

Język polski funkcjonujący na terenach kresowych był przedmiotem zainteresowania wielu badaczy, czego efektem są liczne opracowania na temat polszczyzny na Kresach Południowo-Wschodnich. Należy tu wymienić m.in. publikacje Janusza Riegera, Iwony Cechosz i Ewy Dzięgiel (2002, 2007), Heleny Krassowskiej (2015), a zwłaszcza dotyczące obwodu lwowskiego - Zofii Kurzowej (1983, 1993, 1997), Anny Kosteckiej-Sadowej (2008, 2017), Marii Zielińskiej (2011, 2012) czy Jana Fellerera (2020). Polszczyzna stryjan skupionych wokół Towarzystwa Kultury Polskiej Ziemi Lwowskiej nie była dotąd przedmiotem szczegółowych badań - wstępne analizy zachowań językowych młodszego pokolenia Polaków w Stryju przeprowadzał jedynie Michał Głuszkowski (2007, 2013a, 2014), a sytuacja językowa mieszkającej tam mniejszości była przedmiotem badań pilotażowych prowadzonych przez autorkę niniejszego artykułu (Pawlaczyk 2019a, 2019b).

W Stryju, znajdującym się w obwodzie lwowskim, z myślą o mieszkającej tam mniejszości polskiej powstał oddział Towarzystwa Kultury Polskiej Ziemi Lwowskiej (TKPZL), w którym obecnie jest zarejestrowanych ok. 320 osób. Placówka jest nastawiona m.in. na edukację i rozwój kompetencji językowych jej członków, propagowanie i podtrzymywanie wśród nich polskości, pomoc w dopełnieniu formalności niezbędnych do uzyskania Karty Polaka (Pawlaczyk 2019a, 70). Deklaracja przynależności do organizacji polonijnej powinna być równoznaczna $\mathrm{z}$ aktywnym uczestnictwem $\mathrm{w}$ życiu kulturalnym oraz $\mathrm{w}$ różnego rodzaju przedsięwzięciach organizowanych przez jej przedstawicieli.

W niniejszym artykule podjęto próbę omówienia społecznych uwarunkowań kompetencji językowej przedstawicieli polskiej mniejszości w Stryju na podstawie materiałów zebranych w stryjskim oddziale TKPZL podczas zajęć edukacyjnych, prowadzonych w 2019 roku w trzech grupach wiekowych (dzieci, młodzież, dorośli) w ramach II edycji Letniej Szkoły Języka i Kultury Polskiej. Materiał językowy zbierano dwiema metodami badawczymi. Pierwszą z nich była metoda kwestionariuszowa. Podczas zajęć organizacyjnych każdego z respondentów poproszono o uzupełnienie sporządzonej w języku polskim ankiety, zawierającej następujące pytania:

1) Oceń (0-10) swoją znajomość języków: ukraiński [..]; polski [...]; rosyjski [...]; angielski [...]; inne (jakie?) [...].

2) Od którego roku życia masz kontakt z językiem polskim?

3) Jaki był Twój pierwszy kontakt z językiem polskim?

4) Czy pobierałeś lekcje / uczestniczyłeś w kursach języka polskiego? Jak długo?

5) Kto w Twoim otoczeniu mówi(ł) w języku polskim (dziadkowie, rodzice, rodzeństwo, sąsiedzi, itp.)?

6) Czy jesteś członkiem polskiej organizacji? Jakiej? Czym się zajmujesz?

7) Jakie znasz polskie miasta?

8) Jakich znasz polskich poetów i pisarzy?

9) Jakich znasz polskich aktorów, reżyserów, grupy muzyczne?

10)Jakich znasz polskich sportowców? 
11) Czy byłeś w Polsce? W jakich miastach?

12) Napisz w kilku zdaniach: czym się zajmujesz, czym się interesujesz oraz jak spędzasz wolny czas?

Jej celem było zebranie materiału pisanego, zawierającego przekonania respondentów na temat ich umiejętności językowych ${ }^{1}$, wiedzy dotyczącej Polski i zainteresowań. Zamieszczenie w kwestionariuszu prośby o samookreślenie poziomu znajomości języka było zainspirowane podobnymi badaniami, m.in. projektem Gerda Hentschela, Istvána Feketego i Jolanty Tambor, w którym wykorzystano ankietę socjodemograficzną, stworzoną przez zespół, a dotyczącą m.in. postaw i opinii wyrażanych przez użytkowników śląskiego etnolektu. We wstępnym raporcie z projektu naukowcy wyjaśnili, że celem ich badań stało się zebranie danych nt. zakresu posługiwania się śląskim przez poszczególne grupy wiekowe, ich postaw językowych i oczekiwań oraz liczby germanizmów aktywnie używanych przez Ślązaków (Hentschel, Fekete i Tambor 2019, 19). Dane przedstawione $\mathrm{w}$ raporcie potwierdzają, że wykorzystanie metody ankietowej w badaniach języków regionalnych jest ważne, a odpowiednio dobrana próba badawcza pozwala uznać wyniki za reprezentatywne. Metodę kwestionariuszową wykorzystano również w badaniach dotyczących trójjęzyczności ukraińsko-rosyjsko-polskiej prowadzonych przez Pavlo Levchuka (2020), których celem było przedstawienie sytuacji językowej Ukraińców niepolskiego pochodzenia. Wśród respondentów znalazły się osoby bez polskich korzeni lub z korzeniami śladowymi (deklarujące polskie pochodzenie jednego z pradziadków). W opracowaniu uwzględniono m.in. motywacje do nauki języka polskiego. Oprócz możliwości studiowania, podjęcia pracy zarobkowej czy osiedlenia się w Polsce, często był nią również fakt posiadania polskiego pradziadka (zob. Levchuk 2020, 107-111). Wyniki przeprowadzonych badań socjolingwistycznych, obejmujących głównie osoby bez polskich korzeni, pokazują, że zakres motywacji do nauki języka polskiego na Ukrainie jest szeroki i zróżnicowany, a dopiero perspektywa indywidualna, zwłaszcza z uwzględnieniem retrospekcji, ukazuje pełnię złożoności sytuacji - co potwierdza także niniejsze badanie.

Drugą metodą był wywiad ustny utrwalony na dyktafonie za zgodą informatora, a w przypadku dzieci - za pisemną zgodą rodzica. Wywiady przeprowadzono z informatorami, wyrażającymi chęć omówienia uzupełnionego wcześniej kwestionariusza, co pozwoliło na rozwinięcie przekonań zawartych na piśmie oraz na faktyczną ocenę i weryfikację umiejętności językowych tych osób.

\section{FUNKCJONOWANIE POLSZCZYZNY W STRYJU}

Badania pilotażowe przeprowadzone w 2018 roku w Stryju wykazały, że dla członków TKPZL charakterystyczne okazuje się posługiwanie się więcej niż dwoma językami.

\footnotetext{
${ }^{1}$ Odpowiedzi z ankiety nie były jedynym źródłem określenia poziomu językowego badanych. Umiejętności językowe respondentów autorka niniejszego artykułu weryfikowała w toku zajęć edukacyjnych, prowadzonych w ramach letniej szkoły.
} 
Jednym z czynników determinujących umiejętności komunikacyjne i postawy wobec polszczyzny jest miejsce, w którym dochodzi do kontaktu z językiem przodków, czyli organizacja, w której działa szkoła z językiem polskim i kościół. Dla badaczy te miejsca są o tyle istotne, że umożliwiają nawiązanie kontaktów oraz pozyskanie materiału językowego nie tylko od aktywnych członków organizacji czy od wiernych, lecz także od ich bliskiego otoczenia (rodzina i znajomi). Na podstawie zebranych danych ${ }^{2}$ ustalono, że:

(1) Sytuacja językowa mniejszości polskiej mieszkającej w Stryju jest złożona. Obecnie podstawowym narzędziem komunikacji tych osób jest język ukraiński. Jednak w zależności od sytuacji komunikacyjnej i otoczenia, w którym znajdują się członkowie wspólnoty, dodatkowo mogą oni posługiwać się językiem rosyjskim i/lub polskim. Ten ostatni odgrywa szczególnie istotną rolę podczas zarówno nabożeństw, jak i uroczystości w oddziale TKPZL, a także kontaktów z krewnymi i polskojęzycznymi znajomymi (Pawlaczyk 2019a, 71-72; 2019b, 257-258).

(2) Czynniki historyczno-polityczne, socjologiczne i socjolingwistyczne wpływają na charakter kontaktu językowego oraz na wybór kodu językowego. Zależą od nich również status polszczyzny i postawy wobec niej - dlatego różnice ujawnią się w motywacjach do nauki języka oraz w zachowaniach językowych przedstawicieli poszczególnych pokoleń (Pawlaczyk 2019b, 258).

(3) Wśród głównych czynników wpływających na obecny stan polszczyzny można wyróżnić kraj urodzenia, otoczenie językowe oraz typ rodziny (zob. Pawlaczyk 2019a: 71-75). Z kolei za najważniejsze czynniki motywujące do nauki uznaje się: zetknięcie z polszczyzną w okresie młodości, polskie pochodzenie, chęć uzyskania Karty Polaka, zamiar wyjazdu do Polski, wyznanie (zob. Pawlaczyk 2019a, 76-77).

\section{SPOŁECZNE UWARUNKOWANIA KOMPETENCJI JĘZYKOWEJ UCZESTNIKÓW} LETNIEJ SZKOLY

Kwestionariusze i wywiady nagrane w 2019 roku stanowiły uzupełnienie materiału językowego (pisanego i mówionego) zebranego rok wcześniej i dotyczącego sytuacji językowej mniejszości polskiej, z uwzględnieniem sfer użycia polszczyzny, postawy wobec niej i zjawisk językowych charakterystycznych dla poszczególnych grup

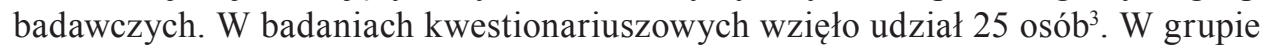
I zostały wypełnione 4 kwestionariusze, w grupie II - 11, natomiast w III - 10 . Z przeanalizowanych ankiet przeprowadzonych w grupie dzieci wynika, że w trzech przypadkach deklarowano znajomość czterech języków, a w jednym - ukraińskiego

\footnotetext{
${ }^{2} \mathrm{~W}$ badaniach z 2018 roku nie stosowano kryteriów doboru grupy badawczej, jednak otrzymane wyniki można uznać za względnie miarodajne. Założenia zweryfikowano i potwierdzono podczas badań prowadzonych w 2019 roku, dlatego wyniki otrzymane rok wcześniej można odnieść do całej społeczności.

${ }^{3} \mathrm{~W}$ niniejszej pracy, ze względu na gwarancję anonimowości, w symbolach zakodowano płeć i wiek respondentów/informatorów (np. CH11 - 11-letni chłopiec, K32 - 32-letnia kobieta).
} 
i rosyjskiego. Znajomość podstawowego kodu językowego (urzędniczego) oceniano w skali od 8 do 10 punktów. Z kolei najsłabiej oceniano znajomość języka polskiego (zob. wykres 1).

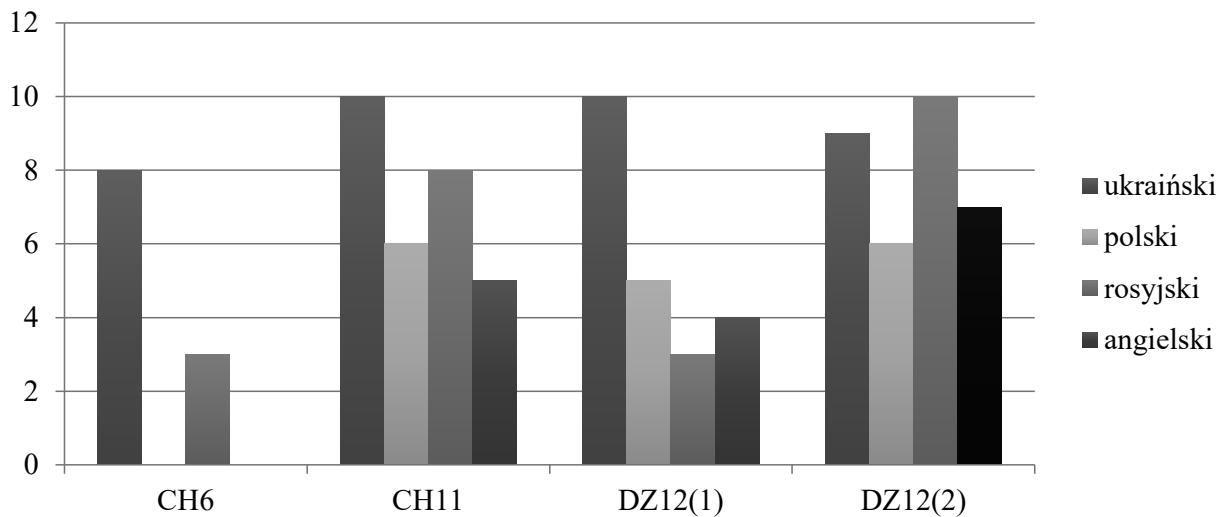

Wykres 1. Skala samooceny znajomości poszczególnych języków w grupie dzieci

Z odpowiedzi na pytanie dotyczące pierwszego kontaktu z polszczyzną wyni$\mathrm{ka}$, że dochodziło do niego dopiero w szkole, mimo że w otoczeniu najmłodszych respondentów posługuje się nią (prawdopodobnie okazjonalnie) któryś z rodziców, dziadków i/lub pradziadków. Trudności przysporzyło pytanie otwarte, polegające na stworzeniu kilkuzdaniowej wypowiedzi pisemnej w języku polskim na temat zainteresowań i sposobów spędzania czasu wolnego. Najmłodszy respondent (9 1.), ze względu na brak umiejętności pisania w wymaganym języku, nie był w stanie udzielić odpowiedzi. Dwie 12-letnie respondentki, wcześniej stosujące się do poleceń zawartych w ankiecie, w przypadku dłuższej wypowiedzi pisemnej udzieliły odpowiedzi w języku ukraińskim:

Я люблю малювати з своєю сестрою. Гуляю кожен день з друзями (DZ12[1])

Займаюсь бальними танцами, болейболом, легкою атлетикою,учобою. В вільний час малюю, читаю, гуляюї відпочиваю [...] (DZ12[2])

Ze względu na barierę językową odczuwalną przez uczestniczki badań oraz na brak swobody rozmowy nie chciały one podjąć się próby omówienia wypełnionych kwestionariuszy. Z kolei czwarty z respondentów (11 1.) stworzył następującą wypowiedź pisemnąa : „Ja bardzo lubie uczyć języki. Lubie czytać i chodzić na spacer. Lubię sport. Wólny czas spędziałem ze swoim bratem i bawę się ze swoimi kolegami”. Chłopiec, mimo niespełna rocznej nauki języka polskiego, opanował go na dobrym poziomie

\footnotetext{
${ }^{4}$ Wypowiedzi pisemne respondentów przytoczono w oryginalnej postaci.
} 
w zakresie czytania i pisania, a na bardzo dobrym - w zakresie mówienia. Potwierdza to zarówno aktywność na zajęciach podczas trwającej szkoły letniej, jak i brak bariery komunikacyjnej podczas udzielanego wywiadu. Respondent ocenił poziom znajomości polszczyzny na 6 punktów:

bo j'a j' ešč'e 'uč'e śe jenz' yka polsk' 'ego ij'a tak na pow'ove zn'am [...] j'a by xć'aw 'um'eć / 'um'eć tak v'olna rozm'av'ać / rozm'av'ać i tr'ox'i jak sw'yše tak i p' 'isać

Podczas zajęć i prowadzonego wywiadu zaobserwowano, że starał się on tworzyć rozbudowane konstrukcje składniowe, przy czym miał świadomość, że nie zawsze okazują się one poprawne pod względem gramatycznym. Dodatkowo CH11 nie miał problemów z właściwym rozumieniem poleceń czy z udzielaniem odpowiedzi na pytania, np.:

- Czym się zajmujesz na co dzień? Co lubisz robić?

j'a 'uč'e śe jenz'yka i / 'iźe na sp'acer / ba... b'av'iw bav' 'iwem śe ze sf'ojim mw'očšym bra... br'at br'atem / j'a l'ub'e č' 'ytać / x'oźić na sp'acer i gr'ać f p' 'iwku n'ožnom

Z zarejestrowanego materiału wynika, że w zakresie fonetyki różnice najczęściej zauważalne są w wymowie spółgłoski č, która przed samogłoską jest wymawiana miękko (č>č'), np. j'ešč'e (pol. ješče), 'uč’e śe (pol. uče śe), č' 'itam (pol. czytam). $\mathrm{Z}$ kolei w zakresie morfologii odnotowano m.in. różnice w użyciu końcówek osobowych czasu przeszłego, które pod wpływem ukraińskiego są ujednolicone we wszystkich osobach, np.: (1) j'a t'utaj x'oźiw na p'olsk'i (por. pol. chodziłem, ukr. Я ходив), (2) j'a b'arzo xć'aw teš na'učyć śe (por. pol. chciałem, ukr. Я хотів), (3) j'a by xć'aw (por. pol. chciałbym, ukr. Я хотів би). Oprócz tego w wypowiedziach informatorów występują zapożyczenia i kalki z języka ukraińskiego, jak w przykładzie: j'a ogl'ondaw k'arte p'olsk'i (por. pol. mapa, ukr. карта). Zakres interferencji jest szeroki i obejmuje różne jej przejawy w zakresie fonetyki, morfologii, leksyki i składni, ale w związku ze skromnym zakresem zarejestrowanego materiału w grupie dzieci szczegółowe analizy wpływów ukraińskich wymagają kontynuacji badań.

W grupie II - młodzieży - siedmiu respondentów zadeklarowało znajomość czterech języków, a pozostali - trzech. Najwyżej oceniano język ukraiński (9-10 punktów). Z kolei najniżej - podobnie jak w grupie dzieci - język polski (zob. wykres 2). 


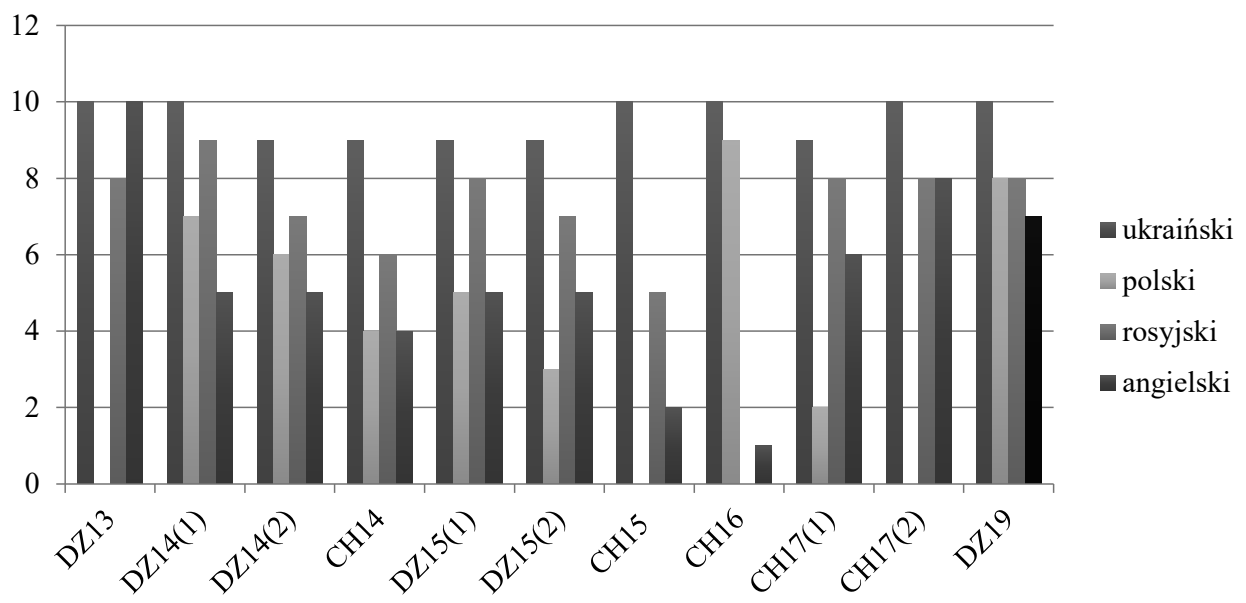

Wykres 2. Skala samooceny znajomości poszczególnych języków w grupie młodzieży

W przypadku pierwszego kontaktu z polszczyzną najwięcej osób odpowiedziało, że dochodziło do niego podczas zajęć $\mathrm{w}$ organizacjach zajmujących się nauczaniem języka (5 osób) oraz wizyty w Polsce ( 3 osoby). Połowa respondentów zadeklarowała, że w ich otoczeniu polszczyzną posługują się jedynie przyjaciele i koledzy, a pozostała część - że nie ma osób mówiących po polsku. Na pytanie dotyczące zajęć, zainteresowań i czasu wolnego udzielono następujących odpowiedzi:

Interesuję się śpiełem. W wolny czas spaceruje z koleżankami, czytam, oglondam filmy (DZ14[1]).

Interesuję się językiem polskim, oglądaniem filmów i seriałów, czytaniem różnych książek. Kiedy mam wolny czas i jest fajna pogoda to wtedy chodzę na spacer, chodzę nad rzeke lub jezioro. Też lubie tańczyć, pływać, czytać, grać siatkówkę (DZ14 [2]).

Interesuję się językami i kulturami różnych narodów, sportem, także lubię spacerowacz razem z koleżankami. Jeszcze teraz uczę angielskiego języku (DZ15[1]).

Uwielbiam rysować, gram na gitarze. Bardzo liubi śpiewać (DZ15[2]).

Zaimuśe plawanim. iteresuje się plituko. wolny cas serwuje internetie (CH16).

Jestem studentką. Interesuję się językami, rysowaniem. Kiedy mam wolny czas, spędzam z przyjacielami, rodzicami. Robię shopping (DZ19)

W pozostałych przypadkach udzielano odpowiedzi w języku ukraińskim. Wynika to przede wszystkim z niewystarczającej znajomości polszczyzny lub z braku umiejętności tworzenia i zapisywania zdań w języku polskim. Najbardziej zaangażowani i aktywni uczestnicy letniej szkoły wyrażali chęć omówienia kwestionariuszy i udzielenia krótkiego wywiadu ustnego. Jedną z takich osób była DZ14(1), która deklarowała polskie pochodzenie, mimo że nie zostało ono poświadczone w żadnych dokumentach. 
Ze względu na odczuwalną barierę językową oraz brak płynności podczas czytania znajomość polszczyzny została przez nią oceniona na 7 punktów. Na podstawie fragmentu książki odczytanego przez informatorkę można stwierdzić, że miękko wypowiada ona spółgłoskę /č/ (np. č’aroźej [por. pol. czarodziej], žeč’ [por. pol. rzecz]), głoskę /ł/ traktuje jako /v/ (np. cavom [por. pol. całą]), a oprócz tego nie realizuje spółgłoski /ć/ (np. čyńic [por. pol. czynić]). Z kolei z przeprowadzonego wywiadu wynika, że DZ14(1) nie miała problemu z rozumieniem pytań. Jednak tworzone przez nią wypowiedzi nie zawsze charakteryzowały się płynnością, swobodą oraz poprawnością gramatyczną:

v vak'ac'e jex'awa do p'olsk'i s tovaž' ystfem / t'agže v g'urax b'ywam dv'a tyg'odńe / no tak to spacer'uje nad ž'ek'e nad jeź' oro / [...] x'oze do šk' owy od 'usmej čšyź' eści do ģ́'eś 'albo čš' ećej 'abo dr'ug'ej goź' iny dń'a / 'albo na nu na l'ekcje t'utaj / 'albo no / po pr'ostu d'oma / [...] č'ytam / r'able r'ob'e zad'ańe dom'ove / nu ji pom'agam m'am'e / [...] rys'uje k' 'edy j'est n'astruj / j'eśe ń'e v'em / nu ogl'ondam f' 'ilmy i ser' 'ale

Nieco inaczej było w przypadku drugiej informatorki - DZ14(2), która swobodnie posługuje się polszczyzną w kontaktach z polskojęzycznymi osobami, co może wynikać z zetknięcia się z nią już we wczesnym dzieciństwie:

m'oj 'ojéec rozm'av'aw po p'olsku i m'oja b'apća ze str'any 'ojca teš / i pšes to zn'am ten j'enzyk j'ešč'e z maw'ego / a p'otem k' 'edy m' 'awam ź' eśeńć l'at to p'ošwam da šk'owy p'olsk'ej mńejš 'ośći narod'ovej f str'yju i uč'ywam ten j'enzyk pšes p' 'enć l'at i d'alej 'uče

Podczas udzielanego wywiadu informatorka wspominała, że odczuwa braki w zakresie gramatyki oraz dostrzega u siebie błędy w akcentuacji wyrazów. Stara się pracować nad błędami i korygować je poprzez uczestnictwo w kursach językowych. Obecnie nie ma problemu z tworzeniem zarówno prostych, jak i rozbudowanych konstrukcji składniowych w języku polskim:

t'eras x'oze do šk'owy p'olsk'ej / teš l'atem b'arzo l'ub'e sp'enzać v'olny č' 'as s koleg'am'i i koležank'am'i / to x'oze nad ž'ek'i / jeźź'imy rov'ežem / v ńekt' uryx v ńekt' užyx r'azax jeźź'imy v g'ury pšez dv'a čš'y dń'i / i tak t'eraz b ede 'iść juš f pońeś' awek do šk' owy / [...] interes 'uje śe muz' ykom sp'ortem tańc 'am'i / bo pšes p' 'enć l'at xoś' iwam 'ale jušńn'e mam tak d'užo č 'asu 'ale t'eras pw'yvam / 'ale j'ešče k' 'edyś xoź' iwam na śatk' ufke [...]

W wypowiedziach DZ14(2) jest zauważalna, podobnie jak u DZ14(1), m.in. miękka

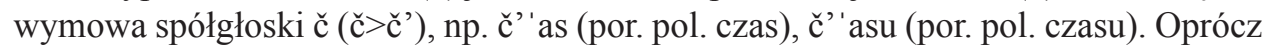
tego formy czasu przeszłego przez nią tworzone odpowiadają często ukraińskiej konstrukcji ,,temat + л + końcówka osobowa”, np. vykonyv'awa t'ak'e pr'ace.

W grupie III (dorośli) liczącej 10 respondentów, czworo z nich zadeklarowało znajomość czterech języków, pięciu - trzech, a jedna - dwóch. Najwyżej oceniano znajomość języka ukraińskiego. Drugim najwyżej ocenianym był język rosyjski, trzecim - polski, a najniżej oceniano znajomość języka angielskiego (zob. wykres 3). W przypadku K74 oraz K85(2) poniższy wykres nie uwzględnia ocen, ponieważ respondentki zadeklarowały jedynie znajomość poszczególnych języków, a nie oceniły poziomu ich znajomości. 


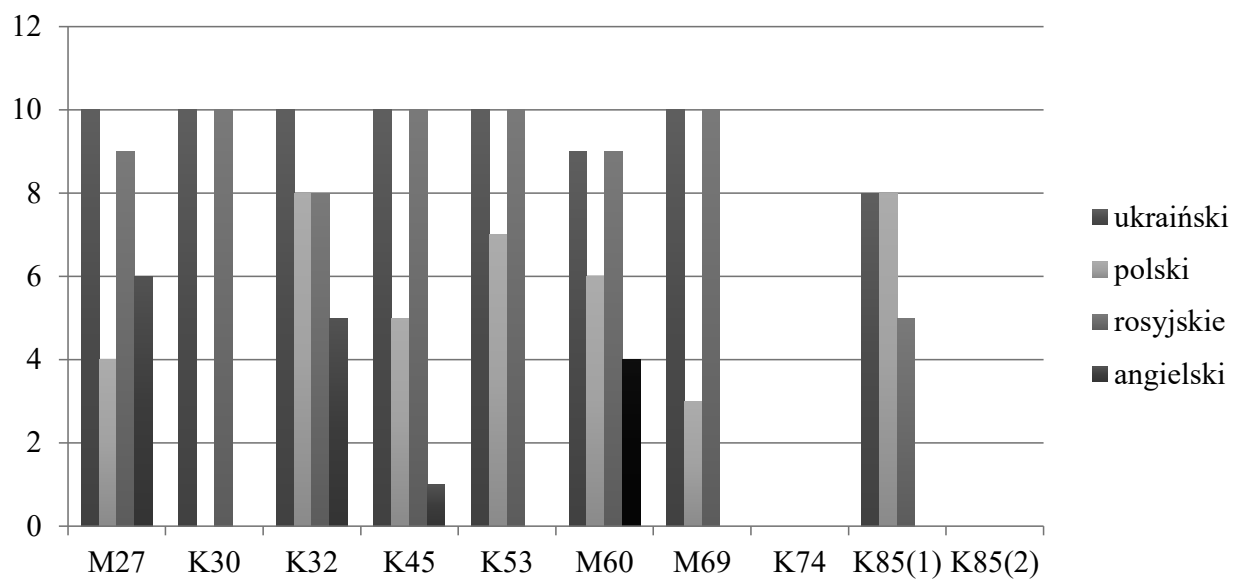

Wykres 3. Skala samooceny znajomości poszczególnych języków w grupie dorosłych

W przypadku dorosłych kontakt z polszczyzną następował już w dzieciństwie, co wynika z wychowywania się w rodzinach, w których podstawowym kodem językowym był język polski. Dlatego do pierwszego kontaktu dochodziło najczęściej podczas rozmów z dziadkami w rodzinnym domu. Innych odpowiedzi udzielały osoby nieposiadające Karty Polaka, czyli pochodzące z rodzin ukraińskich lub mieszanych. W ich przypadku kontakt wynikał z turystyki lub bliskiego sąsiedztwa Polaków. Z pytaniem dotyczącym zajęć, zainteresowań i czasu wolnego kłopot miały trzy osoby, które ze względu na brak znajomości polszczyzny udzieliły odpowiedzi w języku ukraińskim. Pozostałe osoby - zgodnie z prośbą badaczy - w języku polskim:

Pracuję jako inżynier na Stryjskiej Fabryce Wagonowej. Także jestem członkiem TKPZL w Stryju. Przy Towarzystwie zajmuję się teatrem, także prowadziłam zajęcia sekcj krajoznawczo-historycznej. Lubię czytać literature obyczajową w języku polskim lub rosyjskim. Lubię tematykę o II wojnie światowej lub czasach międzywojennych, o zwierzętach. Chcę wyuczyć język angielski. Ostatnio rzadko mam wolny czas, jeżeli go mam, to czytam, śpię lub idę nad rzekę jeżeli pogoda dopasuje (K32)

Pracuje w piekarni. Ale mam dużo zainteresowań. Mam ogród, sad. Lubie gotować. Robić na drótach różne rzeczy (в'язання). Вишивания нитками Oglondać TV (K45)

Jestem pielegnarka, asystenta dentysta, lubie podrużować itd. (K53)

Pracuje jako elektryk na fabryce z remontu wagonów ciężarowych. interesuje się historją, polityką, muzyką. Kiedy wypada wolny czas lubię czytać książki, śpiewać piosenki polski, pracować w ogrodzie (M60)

Jestem emeratorką, chodze na uniwersytet III wieku, w kłub kobiet (K74)

Jestem na emerytuże, pracowala jako krawcowa, lubie spiewać, tanszyć i gotować pyszne jedzenie (K85[1])

Jestem ameratorko, chodze na chur, do kościola (K85[2]) 
Materiał pisany poszerzono o kilka wywiadów ustnych, podczas których omówiono kwestionariusze poszczególnych informatorów, w tym K32. Kobieta posługuje się polszczyzną w zakresie kodu rozwiniętego, według definicji Basila Bernsteina (Bokszański, Piotrowski i Ziółkowski 1977, 106-131; Głuszkowski 2013b, 125-130), co potwierdza fragment jej wypowiedzi:

t'eras prac'uje na fabr'yce vagon'ovej i j'ako inž'yńer 'uče l'uźi vykožyst yvać r'užne progr'amy komputer'ove / teš č' asem prac'uje j'ako oper'ator / nab' 'eram r'užne d'ane / vb' 'ijam do progr' amy pewn 'ego no i t' ak'e suprov' od j' agby progr' amuf r' užnyx / 'opruč t' ego j' ešče j́' ałam pšy tovaž' ystf'e / j'estem čł' onk'em zaž' ondem / na tovaž' ystf'e to zajm'uje śe te'atrem i j'ešče provaź' iwam zaj'enća x'istor' yčne pšez dv'a l'ata / '̧' 'enk'i ń'im tr' oxe vyuč' yłam x'ist' or'i p'olsk'i

Z polszczyzną K32 ma kontakt od 15. roku życia. Swoje umiejętności językowe oceniła na 8 (w skali 1-10), ponieważ odczuwa braki w słownictwie oraz brak swobody komunikowania się z osobami polskojęzycznymi. Obecne w wypowiedziach wpływy wschodniosłowiańskie wynikają z jej pochodzenia (ukraińsko-rosyjsko-polskie) oraz liczby języków używanych w kontaktach z domownikami (ukraiński, rosyjski). Zarówno w materiale pisanym, jak i w mówionym odnotowano m.in. kalki gramatyczne - składniowe, np. (1) „Pracuję na Stryjskiej Fabryce Wagonowej” (por. pol. Pracuję w Stryjskiej Fabryce Wagonowej, ukr. Працюю на Стрийському вагоноремонтному заводі), (2) ,pracuje na fabryce wagonowej” (por. pol. pracuję w fabryce wagonowej, ukr. працюю на вагоноремонтному заводі), (3) „zaczęłam chodzić na towarzystwo” (por. pol. zaczęłam chodzić do towarzystwa, ukr. почала ходити на товариство)

$\mathrm{Z}$ ankiet wypełnionych przez respondentów udało się również wynotować ciekawe formy zapisu niektórych konstrukcji. W odpowiedziach na pytanie „Od którego roku życia masz kontakt z językiem polskim?” pojawiały się błędy typu „od X lat”, co miało odpowiadać polskiemu „od X roku życia”, np.: „od 3 lat”, „ot 14 lat”. W pisemnych wypowiedziach najstarszych respondentów pojawiała się również ukraińska konstrukcja „3 X року”, odpowiadająca polskiemu „od X roku”, np.: „z 1945 r.”, „Mam kontakt z językiem polskim z $1961 \mathrm{r}$.". Jedną z najbardziej interesujących form interferencji były nazwiska i nazwy miast, zapisywane przez respondentów. Odnotowano:

- odchylenia od norm polskiej pisowni, np.: „Chenstochowa” (por. pol. Częstochowa), „Ludz” (por. pol. Łódź), „Bydgosz” (por. pol. Bydgoszcz);

- próby transliteracji nazw miast np. „Wrotslaw” (por. pol. Wrocław), „Warshawa” (por. pol. Warszawa);

- ślady angielskiej ortografii podczas prób transliteracji nazwisk poetów, gdzie głosce [č] odpowiada ch, a [̌̌ ] - sh, np. „Mickiewich”, „Mickewych”, „Mickewich” (por. pol. Mickiewicz), „Makushinski” (por. pol. Makuszyński), „Sienkewich" (por. pol. Sienkiewicz).

\footnotetext{
${ }^{5} \mathrm{~W}$ przykładzie (1) i (2) przyimek $w$ został zastąpiony przez $n a$, co można uznać za wynik oddziaływania języka ukraińskiego. Podobny wpływ staje się zauważalny w przykładzie (3), w którym zamiast przyimka do pojawia się ukraiński odpowiednik - na.
} 
Oprócz tego w ankietach znalazły się również przykłady tworzenia form czasu przeszłego czasowników za pomocą ukraińskiej konstrukcji „temat + л + końcówka osobowa”, np.: „W Polsce potem poszła do polskiej szkoły”, „uczyła język polski 4 lata”, „Brała udzial w kursach”.

\section{PODSUMOWANIE}

Stryjanie skupieni wokół TKPZL stanowią ciekawą, dotąd niezbadaną grupę. Na podstawie zgromadzonego materiału można stwierdzić, że obecnie podstawowym narzędziem ich komunikacji jest język ukraiński. Polszczyzna jest przez nich używana okazjonalnie (osoby mające polskie pochodzenie), albo - w przypadku osób dopiero rozpoczynających naukę języka - praktycznie w ogóle nie jest przez nich używana. Zarówno w ankietach, jak i w wywiadach przedstawiciele mniejszości, ze względu na konieczność zapisu wypowiedzi i prowadzenia rozmowy wyłącznie w języku polskim, przejawiali dbałość o zgodność z jego normą literacką. O ile w przypadku kwestionariuszy treść wypowiedzi pisemnych mogła być przez nich kontrolowana i z reguły odpowiadała normie literackiej (z wyjątkiem ortografii), o tyle w przypadku wywiadów - niemożliwe stawało się jednoczesne kontrolowanie treści wypowiedzi i panowanie nad wymową, co potwierdzają pojawiające się przykłady interferencji. Z analizowanych materiałów wynika, że osoby reprezentujące pokolenia młodsze i średnie często nie miały kontaktu z polszczyzną w dzieciństwie i przez długi czas nie były świadome swojego polskiego pochodzenia - dlatego w sytuacjach codziennych posługiwały się wyłącznie językiem ukraińskim i/lub rosyjskim. Zaobserwowano, że te osoby mają dużą motywację do nauki języka polskiego: często podejmują się jej samodzielnie lub uczęszczają na dodatkowe lekcje. Oprócz tego zauważono, że podczas prowadzonych wywiadów wypowiedzi były przez przedstawicieli wspomnianych grup konstruowane z dużą dbałością o zgodność z normą literacką, jednak spontaniczna zmiana tematu rozmowy pozwalała na dokładniejszą ocenę umiejętności językowych i weryfikację pojawiających się odchyleń od normy. W pokoleniu młodszym i średnim okazywały się one najbardziej widoczne na poziomie gramatycznym i leksykalnym. Z kolei analiza materiału językowego zebranego w grupie dorosłych (zwłaszcza wywiady ustne nagrane w języku polskim) pokazała, że do pierwszego kontaktu przedstawicieli pokolenia starszego z polszczyzną dochodziło najczęściej w rodzinnym domu, w którym używano jej w codziennej komunikacji. Mimo że obecnie informatorzy posługują się nią już tylko okazjonalnie, to można zaobserwować wysoki poziom jej zachowania - co potwierdzają rozbudowane i bogate w różnorodne środki językowe konstrukcje składniowe, tworzone przez te osoby. Nie oznacza to, że wypowiedzi są wolne od obcych wpływów, ale należy zaznaczyć, że odchylenia od normy są w mowie informatorów rzadziej obserwowalne.

Polszczyzna zajmuje wysoką pozycję w systemie wartości członków polskiej wspólnoty. Jej wysoki prestiż wynika m.in. z chęci podtrzymania rodzinnych tradycji i zachowania języka przodków. Na obecny stan języka polskiego w poszczególnych pokoleniach wpływały przede wszystkim takie czynniki, jak miejsce urodzenia, typ 
rodziny i otoczenie językowe. Choć obecnie polszczyzna jest używana prawie wyłącznie w sferze religijnej, zauważa się, że zainteresowanie nią rośnie - zwłaszcza w pokoleniu osób urodzonych po 1991 roku, co wynika przede wszystkim z więzów krwi (jeden z ważniejszych czynników motywujących do nauki) oraz z jej atrakcyjności.

\section{BIBLIOGRAFIA}

Bokszański, Z., A. Piotrowski, i M. Ziółkowski. 1977. Socjologia języka. Warszawa: Wiedza Powszechna. Fellerer, J. 2020. Urban Multilingualism in East-Central Europe. The Polish Dialect of Late-Habsburg Lviv. Lanham - Boulder - New York - London: Lexington Books.

Głuszkowski, M. 2007. „Âzykovaâ situaciâ i kul'turnoe samosoznaniedetej i molodeži Pol'skogo Kul'turnogo Centra im. Kornelâ Makušinskogo v Strye”. W Krymsko-pol'skijsbornik naučnyh rabot. T. 5: Dni Adama Mickeviča v Krymu, red. A. Gadomski. Simferopol': Universum, 205-212.

Głuszkowski, M. 2013a. „Wpływ postawy wobec języka na charakter kontaktu językowego. Na przykładzie sytuacji językowej dzieci i młodzieży z Polskiego Centrum Kulturalnego w Stryju (Ukraina)". W Dialog kultur. Języki wschodniostowiańskie w kontakcie z polszczyzna i innymi językami europejskimi, red. J. Mędelska, i E. Titarenko. Bydgoszcz: Wydawnictwo Uniwersytetu Kazimierza Wielkiego, 21-32.

Głuszkowski, M. 2013b. Socjologia w badaniach dwujęzyczności. Toruń: Wydawnictwo Naukowe Mikołaja Kopernika.

Głuszkowski, M. 2014. „Rola Polskiego Centrum Kulturalnego w kształtowaniu kompetencji językowej i przyszłych losów tamtejszej młodzieży polskiego pochodzenia”. W Polskie Kresy Wschodnie i ludzie stamtad. II edycja, red. W. Dzianisava, P. Juszkiewicz, i A. Okuskaite. Warszawa: Elipsa, 171-177.

Hentschel, G., I. Fekete, i J. Tambor. 2019. „Głos w sprawie aktualnego stanu użycia zapożyczeń niemieckich we współczesny, etnolekcie śląskim i postaw językowych jego użytkowników (raport wstępny z projektu badawczego)". Forum Lingwistyczne 6: 17-42.

Kostecka-Sadowa, A. 2008. „Stan współczesnej polszczyzny Mościsk i okolic”. W Wspótczesna polszczyzna: stan, perspektywy, zagrożenia, red. Z. Cygal-Krupa. Tarnów: Państwowa Wyższa Szkoła Zawodowa w Tarnowie, 247-257.

Kostecka-Sadowa, A. 2017. „Sytuacja języka polskiego w obcym otoczeniu językowym. Zarys problematyki (na przykładzie obwodu lwowskiego)”. Prace Językoznawcze 19 (2): 73-86.

Krasowska, H. 2015. „Stan badań nad polszczyzną południowokresową. Przeszłość i perspektywy badawcze”. W Język polski i polonistyka w Europie Wschodniej. Przeszłość i wspótczesność, red. I. Bundza, E. Kowalewski, A. Krawczuk, i O. Slyvynskij. Kijów: INKOS, 55-68.

Kurzowa, Z. 1983. Polszczyzna Lwowa i Kresów potudniowo-wschodnich do 1939 roku. Warszawa - Kraków: Państwowe Wydawnictwo Naukowe.

Kurzowa, Z. 1993. O mowie Polaków na kresach wschodnich. Kraków: Wydawnictwo i Drukarnia „Secesja”. Kurzowa, Z. 1997. „Historia i współczesność języka polskiego na Kresach południowo-wschodnich”. W Historia i wspótczesność języka polskiego na Kresach wschodnich, red. I. Grek-Pabisowa. Warszawa: Slawistyczny Ośrodek Wydawniczy, 111-165.

Levchuk, P. 2020. Trójjęzyczność ukraińsko-rosyjsko-polska Ukraińców niepolskiego pochodzenia. Kraków: Wydawnictwo Księgarnia Akademicka. 
Pawlaczyk, A. 2019a. „Funkcjonowanie języka polskiego i elementów polskiej tradycji narodowej w Stryju (Ukraina)". Zeszyty Łużyckie 53: 69-83.

Pawlaczyk, A. 2019b. „Sytuacja językowa mniejszości polskiej w Stryju (Ukraina)”. Rozprawy Komisji Językowej ŁTN 67: 251-261.

Rieger, J., I. Cechosz, i E. Dzięgiel. 2002. Język polski na Ukrainie w końcu XX wieku. Cz. I: Stan i status polszczyzny. Gwary polskie w Lwowskiem, na Tarnopolszczyźnie i na Podolu. Warszawa: Wydawnictwo Semper.

Rieger, J., I. Cechosz, i E. Dzięgiel. 2007. Język polski na Ukrainie w końcu XX wieku. Cz. II: Polszczyzna w Lwowskiem, Żytomierskiem i na Podolu. Teksty. Kraków: Wydawnictwo Lexis.

Zielińska, M. 2011. „Rola polszczyzny w życiu młodych użytkowników języka polskiego na Ukrainie Zachodniej”. Język, Komunikacja, Informacja 6: 127-134.

Zielińska, M. 2012. „Sytuacje komunikacyjne a umiejętności tworzenia wypowiedzi przez młodych użytkowników języka polskiego na terenach Ukrainy Zachodniej”. SŁOWO. Studia językoznawcze 3: 192-200.

\title{
Social determinants of the linguistic competence of Polish minority representatives in Stryi (the Lviv region)
}

Keywords: linguistic competence, language situation, Polish minority, Stryi.

\begin{abstract}
The situation of the Polish minority living in Stryi is not clear-cut. Depending on the communication situation, members of the community speak Ukrainian, Russian or Polish. The latter is used mainly in contacts with Polish-speaking relatives and friends, during church masses and celebrations held at the Society of Polish Culture of the Lviv Region (TKPZL). The article attempts to discuss the social conditions of the linguistic competence of the Polish minority representatives. The language material was obtained during the summer school held in 2019 at the Stryi branch of TKPZL, its results were compared with those of the 2018 pilot study at the same institution.

Two methods were used in the research - a questionnaire and an interview. The aim of the first one was to collect written material on the beliefs of respondents, among others, about their language skills. The second method allowed the informants (expressing their willingness to discuss the previously completed questionnaire) to develop their written beliefs and the actual assessment and verification of their skills.

The analysis of the collected material showed that the Ukrainian language is currently the basic communication tool for the representatives of the Polish minority in Stryi, and the Polish language is used either occasionally or practically not at all. Both in the questionnaires and in the interviews, the respondents/informants took care to comply with the literary norm of the Polish language. The spontaneous change of the topic of the conversation during the interviews allowed for a more precise assessment of language skills and the verification of deviations from the norm in the statements. In the course of the conducted research, it was shown that the Polish language has a high position in the value system of the Polish minority representatives in Stryi, which stems from, among others, the will to preserve the language of the ancestors and maintain family traditions. Although nowadays it is used occasionally, there has been an increased interest in it in all generations, especially in the younger generation, which results not only from blood ties, but also from its attractiveness.
\end{abstract}

